\title{
Impact study on model livestock community development programme in some selected areas of Bangladesh
}

\author{
M.T. Uddin ${ }^{1 *}$, M.M. Islam ${ }^{2}$ and M. Nasrin ${ }^{1}$ \\ ${ }^{1}$ Bangladesh Agricultural University, Mymensingh- 2202, Bangladesh, ${ }^{2}$ Socio-Economic Research \\ Division, Bangladesh Livestock Research Institute, Savar, Dhaka-1341, Bangladesh
}

\begin{abstract}
With a view to increase the productivity of existing backyard livestock and poultry production systems and thereby to improve the socio-economic status of the rural people, BLRI in collaboration with the Department of Livestock Services (DLS) initiated the study since April 2010. The specific objectives of the study were to disseminate the livestock technologies for increasing productivity through training and demonstration and to assess the impact of technological interventions on livestock productivity, socioeconomic improvement and changing livelihood status of rural farm families. The study was implemented initially at Kadamtoli under Belkuchi Upazila under Serajganj district and Chakpara and Bichamara villages under Naikhongchari Upazila under Banderban district which was later extended to Talukhabu village of Gongachara Upazila under Rangpur district. Through this project. technological support was provided to a total of 321, 218 and 780 farm households in Belkuchi, Naikhongchari and Gangachara upazila, respectively. In order to conduct the impact study, 90 farmers taking 30 from each Upazila were selected through simple random sampling technique. The 'before' and 'after' comparison was followed for assessing the impact. The t-statistic was applied to test the significance of relevant parameters. It was revealed that technological intervention has resulted to increase in livestock and poultry population and increase in productivity of milk (19-40\%), duck and chicken eggs (22-36\%) both horizontally and vertically. There was no occurrence of death of cattle, goat and poultry birds. Farmer's overall income was boosted up which has contributed to possession of new household assets and addition of the already available assets. The consumption of all food items was increased as well. It was recommended that the programme may be replicated to other locations with new interventions.
\end{abstract}

(Key words: Production system, productivity, livelihood and technological intervention)

\section{Introduction}

Given the basic structure of Bangladesh agriculture, virtually livestock and poultry are kept in small farms for which animal raising is a secondary and generally supportive activity to crop farming. This sub-sector contributes significantly to the health and economy of rural communities and the nation as a whole. In addition to main economic trains, livestock and poultry also contributes to the production of organic fertilizer and fuel and in the use of marginal nutritional resources which are not directly accessible to mankind.

*Corresponding author; tajbau@yahoo.com

Bang. J. Livs. Res. Vol. 20 (1 \& 2), 2013: P. 88-100 ISSN 1022-3851 
The backyard livestock and poultry production especially goat and poultry farming are less capital-intensive than larger enterprises and can often be financed by dormant rural savings. Livestock is owned by individual households and mostly maintained under scavenging system with little or no inputs for housing, feeding or health care. Indigenous animals and birds still meet more than $50 \%$ of meat and egg requirement.

With variety of advantages, this sub-sector especially backyard system has not yet been developed in relation to crop. A considerable number of animals and birds die each year due to outbreak of different known and unknown diseases. A number of development programmes has so far been launched by GOs and NGOs for the development of backyard production system in addition to commercial/semi-commercial one for the sake of improving livelihood of rural people. Bangladesh Livestock Research Institute (BLRI) also lies in the stream with slightly different views and perspective.

With a view to increase the productivity of existing backyard livestock and poultry production systems and thereby to improve the socioeconomic status of the rural people, BLRI in collaboration with Department of Livestock Services (DLS) initiated this study since April 2010.

The study was planned towards reducing morbidity and mortality of livestock animals and poultry birds through routine vaccination and proper medication, awareness build-up for technology adoption through training, increasing productivity of existing stock under subsistence farming conditions through technological interventions and livelihood improvement of livestock community including women empowerment. The study was undertaken with the following specific objectives:

i. To disseminate the livestock technologies for increasing productivity through training and demonstration; and

ii. To assess the impact of technological interventions on livestock productivity, socio-economic improvement and livelihood changes of rural farm families.

\section{Materials and Methods}

The study was implemented at Belkuchi Upazila under Serajganj district and Naikhongchari Upazila under Banderban district. Kadamtoli village under Belkuchi Upazila and Chakpara and Bichamara villages under Naikhongchhari Upazila were selected as the study villages. Later, the study was expanded at Talukhabu village of Gongachara Upazila under Rangpur district in 2011. Through this project, technological support was provided to a total of 321,218 and 780 farm households in three Upazilas, respectively. Among them, thirty farmers from each district (a total of 90 farmers) were selected for assessing the impact of technological interventions.

The field survey was done with a structured questionnaire. The data and information collected from field surveys, interviews, 
discussions and communications were scrutinized, classified, edited and coded. For analyzing the data, descriptive statistics such as sum, average and percentages were used. The 'before and after' comparison was followed for assessing the impact of technological interventions. The average impact on farmers' income was measured as follows:

$$
\bar{I}=\frac{1}{n} \sum_{i=1}^{n}\left(O_{i}^{T}-O_{i}^{C}\right)(\text { Ravallion, 2008) }
$$

Where, I = Impact (also known as causal effect or gain); $\mathrm{O}=$ Value of the interpretable impact indicator; $\mathrm{T}=$ Treatment group; $\mathrm{C}=$ Control group; $\mathrm{i}=$ Sample units; and $\mathrm{n}=$ Sample size.

The t-statistic was applied to test the significance of relevant parameters. Expenditure elasticity was also estimated using the following formula:

$$
\mathrm{EY}=\Delta \mathrm{Y} / \Delta \mathrm{I} . \mathrm{I} / \mathrm{Y}
$$

Where, $\mathrm{EY}=$ Expenditure elasticity; $\Delta \mathrm{Y}=$ Change in Expenditure;

$\Delta \mathrm{I}=$ Change in income;

$\mathrm{Y}=$ Expenditure before intervention; and I = Income before intervention.

The major activities of the project were: baseline survey, distribution of improved Black Bengal buck among the farmers, vaccination and healthcare services, demonstration and field day, farmers' training, monitoring and advisory services, video documentation and impact study.

\section{Results and Discussion}

\section{Farm and Family Information}

It was revealed that about 33 farmers in Belkuchi upazila and 8 farmers in Bangachara had no homestead land of their own. They used government/khash land for homestead usually by the side of embankment/road. Again 148 and 24 farmers possessed no cultivable land at all in Belkuchi and Gangachara, respectively. They were mostly labourers involved predominantly in fabrics manufacturing along with seasonal agricuitural activities in the village. Average farm size was higher in Naikhongchari (2.411 acres) than Gangachara $(0.550$ acre $)$ and Belkuchi (0.251 acre) upazilas (Table 1$)$. In all the Upazilas, each farm family had almost equal proportion of male and female members. On an average, Naikhongchari had a higher family size (6.15) followed by Belkuchi (5.09) and Gangachara (4.74). However, the family size in Naikhongchari and Belkuchi was higher than the national average (4.9) of the country (BBS, 2010). Agriculture was the main occupation of the farm families whereas agriculture plus service was the second major occupation in Belkuchi and Naikhingchari areas. In Gangachara. agricultural activities and labour selling in seasonal agricultural operations, industry, etc. $(43.02 \%)$ were the prominent occupation (Table 2).

No land was spared for fodder cultivation, even in the Rabi season. Other than cropping season, crop fields were remained fallow for a short time period after harvesting the crops. 
Table 1. Farm and family information

\begin{tabular}{l|c|c|c}
\hline Particulars & Belkuchi & Naikhongchari & Gangachara \\
\hline A. Farm family (No.) & 321 & 218 & 780 \\
B. Farm size (acre/farm) & & & \\
$\quad$ i. Homestead & $0.041(16.53)$ & $0.261(10.84)$ & $0.139(25.27)$ \\
$\quad$ ii. Pond/ditch & $0.011(4.57)$ & $0.572(23.72)$ & $0.036(6.55)$ \\
$\quad$ iii. Cultivable land & $0.197(78.51)$ & $0.631(26.18)$ & $0.373(67.82)$ \\
$\quad$ iv. Fallow/seasonal fallow & $0.002(0.71)$ & $0.947(39.24)$ & $0.002(0.36)$ \\
Total & $0.251(100.00)$ & $2.411(100.00)$ & $0.550(100.00)$ \\
C. Family size (No./farm) & & & \\
i. Male & $1.83(35.95)$ & $1.78(29.34)$ & $1.76(37.13)$ \\
ii. Female & $1.67(32.81)$ & $1.74(28.74)$ & $1.66(35.02)$ \\
iii. Child & $1.60(31.43)$ & $2.63(43.34)$ & $1.32(27.85)$ \\
Total & $5.09(100.00)$ & $6.15(100.00)$ & $4.74(100.00)$ \\
\hline
\end{tabular}

Source: Benchmark survey report, 2010 \& 2011 and field survey, 2012 \& 2013.

Note: Figures within the parentheses indicate percentages of total.

Table 2. Occupation of farm family (\% of population)

\begin{tabular}{lcc|c}
\hline Occupation & Belkuchi & Naikhongchari & Gangachara \\
\hline i. Agriculture & 30.10 & 38.44 & - \\
ii. Labour (agril. and non -agril. activities) & 13.12 & 2.05 & 23.61 \\
iii. Service & 2.72 & 2.70 & - \\
iv. Business & 1.15 & 3.15 & 4.07 \\
v. Agriculture + Service & 22.30 & 21.00 & 10.1 \\
vi Agriculture + Labor & 15.15 & 10.46 & 43.02 \\
vii. Business + Service & 2.12 & 0.45 & - \\
viii. Service + Labor & 0.65 & 0.45 & - \\
ix. Business + Labor & 3.02 & 0.45 & 0.86 \\
ix. Agriculture + Bu siness & 4.22 & 14.00 & 14.46 \\
x. Agriculture + Service + Labor & 3.45 & 0.86 & - \\
xi. Agriculture + Business + Service & 1.05 & 5.50 & 1.88 \\
xii. Agriculture + Business + Labor & 0.95 & 0.49 & 2.00 \\
Total & 100.00 & 100.00 & 100.00 \\
\hline
\end{tabular}

Source: Benchmark survey report. 2010 \& 2011 and field survey, 2012 \& 2013.

Therefore, there was no scope of fodder crop production in the villages away from cropping season. After the intervention, BLRI developed HYV Napier 1 was delivered to 14 farmers of Belkuchi covering the area of 100 decimals and 18 farmers of Gangachara in order to expand such improved feed cultivation among the livestock rearers and thereby to improve livestock productivity.

\section{Information on livestock productivity livestock and poultry possession}

Table 3 reflects a positive change of possession of livestock and poultry species in three locations which is presumably due to proper and timely vaccination in the areas that ultimately reduced mortality. The number of livestock species in each farm family was very small before the 
Table 3. Change of possession of livestock and poultry in three locations (Number)

\begin{tabular}{lcc|c|c|c|c|c|c|c}
\hline Species & \multicolumn{3}{c}{ Belkuchi } & \multicolumn{3}{c|}{ Naikhongchari } & \multicolumn{3}{c}{ Gangachara } \\
\cline { 2 - 10 } & Before & After & $\begin{array}{c}\% \\
\text { change }\end{array}$ & Before & After & $\begin{array}{c}\% \\
\text { change }\end{array}$ & Before & After & $\begin{array}{c}\% \\
\text { change }\end{array}$ \\
\hline Cattle & 0.82 & 0.93 & +13 & 1.90 & 2.04 & +7 & 1.21 & 1.57 & +30 \\
Goat & 0.19 & 0.22 & +16 & 1.01 & 1.07 & +6 & 1.15 & 1.53 & +33 \\
Sheep & 0.11 & 0.14 & +27 & 0.06 & 0.07 & +17 & 0.13 & 0.16 & +23 \\
Chicken & 6.07 & 8.92 & +47 & 13.46 & 15.77 & +17 & 4.71 & 5.48 & +16 \\
Duck & 7.56 & 8.20 & +10 & 1.24 & 1.35 & +9 & 0.92 & 1.17 & +27 \\
Pigeon & 0.37 & 0.59 & +59 & 0.76 & 0.98 & +30 & 0.81 & 1.09 & +35 \\
Pig & - & - & - & 0.13 & 0.17 & +28 & - & - & - \\
\hline
\end{tabular}

Source: Benchmark survey report, 2010 \& 2011 and field survey, $2012 \& 2013$.

intervention. Most of livestock species were indigenous/local. Some people in Belkuchi and Gangachara reared crossbred cattle but there were no crossbred cattle in Naikhongchari. Some of the tribal farmers used to rear pig of cross-breed type. With a few exceptions, almost all farm families were rearing poultry either chicken or duck or both. Some people also reared pigeon predominantly.

Number of all animals and birds were increased within one year period, the incremental rate is higher in Belkuchi $(10-59 \%)$ followed by Naikhongchari (6-30\%) and Gangachara (16-35\%).

\section{Livestock productivity}

A positive impact on productivity of animals and birds was observed in the villages. All these changes in production were statistically significant as tested by the t-statistic (Table 4). Higher milk production in Belkuchi (40\%) is attributed due to feeding BLRI developed Napier 1 compared to Gangachara and Naikhongchari regions.
Before the programme, productivity of existing stock in the villages was low due to inadequate feed and fodder along with poor genetic characteristics. But after the programme, productivity of dairy cattle, poultry and duck was increased horizontally as there is no death occurrence and vertically due to de-worming, routine vaccination of all animals, good feeding and health management.

\section{Product marketing}

The villagers usually sold their product mostly in the local markets. Some farmers sold their product directly from farmgate/homestead.

Necessary input suppliers are now available at the villages and they sell the inputs including feed to the farmers in the agreement that owners will sell their products to the same input suppliers in order to pay back the outstanding amount. 
Table 4. . Impact on productivity of livestock and poul

\begin{tabular}{|c|c|c|c|c|c|c|c|c|c|}
\hline \multirow[t]{2}{*}{ Parameters } & \multicolumn{3}{|c|}{ Belkuchi } & \multicolumn{3}{|c|}{ Naikhongchari } & \multicolumn{3}{|c|}{ Gangachara } \\
\hline & $\begin{array}{c}\text { Milk } \\
\text { (litre/day) }\end{array}$ & $\begin{array}{l}\text { Chicken } \\
\text { egg } \\
\text { (number } \\
\text { /year) }\end{array}$ & $\begin{array}{l}\text { Duck } \\
\text { egg } \\
\text { (number } \\
\text { /year) }\end{array}$ & $\begin{array}{l}\text { Milk } \\
\text { (litre/ } \\
\text { day) }\end{array}$ & $\begin{array}{l}\text { Chicken } \\
\text { egg } \\
\text { (number } \\
\text { /year) }\end{array}$ & $\begin{array}{c}\text { Duck } \\
\text { egg } \\
\text { (number } \\
\text { /year) }\end{array}$ & $\begin{array}{c}\text { Milk } \\
\text { (litre/day) }\end{array}$ & $\begin{array}{l}\text { Chicken } \\
\text { egg } \\
\text { (number } \\
\text { /year) }\end{array}$ & $\begin{array}{c}\text { Duck egg } \\
\text { (number } \\
\text { /year) }\end{array}$ \\
\hline Before & 1.8 & 52 & 72 & 0.89 & 58 & 65 & 1.55 & 51.50 & 77.02 \\
\hline After & & 68 & 86 & 1.25 & 65 & 73 & 1.92 & 70.20 & 94 \\
\hline $\begin{array}{l}\text { Change in } \\
\text { production }\end{array}$ & $\begin{array}{c}0.35 \\
(+19)\end{array}$ & $\begin{array}{c}16 \\
(+30)\end{array}$ & $\begin{array}{c}14 \\
(+19)\end{array}$ & $\begin{array}{c}0.36 \\
(+40)\end{array}$ & $\begin{array}{c}7 \\
(+13)\end{array}$ & $\begin{array}{c}8 \\
(+13)\end{array}$ & $\begin{array}{c}0.37 \\
(+24)\end{array}$ & $\begin{array}{c}18.7 \\
(+36)\end{array}$ & $16.98(+22)$ \\
\hline & & & & & & & & & \\
\hline & $2.19^{*}$ & $4.51 * *$ & $3.93 * *$ & $3.17 * *$ & $2.42 *$ & $2.04 * *$ & $1.96^{*}$ & $3.11^{* *}$ & $2.04^{*}$ \\
\hline
\end{tabular}

Source: Benchmark survey report, $2010 \& 2011$ and field survey, $2012 \& 2013$.

Note: Figures with in the parentheses indicate percentage; ${ }^{* *}$ Significant at 5 percent level; and * Significant at 10 percent level of significance.

\section{Livestock and poultry health perspective major diseases}

Foot and mouth disease (FMD) was the most widely spread livestock disease affecting health and productivity of cattle in each year.

Ruminal impaction and skin disease were more or less common for cattle.

Ranikhet was the most common disease causing massive loss of chicken followed by Pox, NSRD, chicken infectious anaemia and coccidiosis. Similarly, plague was the commonly prevailed disease in duck. PPR and contagious ecthyma were major issues affecting goat health and production in Naikhongchari Parasitic infection was the most common disease in case of pig.

\section{Mortality of livestock and poultry}

After intervention, there was no occurrence of death of cattle and goat in the villages due to proper vaccination against fatal infectious diseases (Table 5). It was observed that before intervention a large number of livestock and poultry birds were infected with infectious diseases resulting to higher percentage of mortality.

\section{Employment generation}

Agribusiness was developed and new employment opportunity was created in the study villages. Altogether 12 broiler farms were initiated by the training recipients which were running successfully. Women empowerment was increased and they have participation in different income generating activities. Gender participation in livestock and poultry keeping were assessed with respect to labour hour devoted every day for this purpose (Table 6). Generally, cattle were reared separately from goat and sheep even in the same shed. Chicken and duck were remained in the same house. Labour hour devoted by family members was increased for all enterprises after intervention. Women were spending more time on rearing different livestock animals. Children are also engaged in livestock and poultry rearing in the villages. 
Table 5. Impact of vaccination on mortality of livestock and poultry

\begin{tabular}{|c|c|c|c|c|c|c|c|}
\hline \multirow{2}{*}{ Species } & \multirow{2}{*}{ Name of diseases } & \multicolumn{2}{|c|}{ Belkuchi } & \multicolumn{2}{|c|}{ Naikhongchari } & \multicolumn{2}{|c|}{ Gangachara } \\
\hline & & $\begin{array}{c}\text { Before } \\
(\%)\end{array}$ & $\begin{array}{c}\text { After } \\
(\%)\end{array}$ & $\begin{array}{c}\text { Before } \\
(\%)\end{array}$ & $\begin{array}{c}\text { After } \\
(\%)\end{array}$ & Before $(\%)$ & $\begin{array}{l}\text { After } \\
(\%)\end{array}$ \\
\hline \multirow{5}{*}{ Cattle } & $\mathrm{FMD}^{*}$ & $1.3(3)$ & - & $0.3(1)$ & - & & - \\
\hline & Black Quarter* & $0.4(1)$ & - & $0.7(3)$ & - & & - \\
\hline & HS* & - & - & $0.3(1)$ & - & - & - \\
\hline & Anthrax* & - & - & $0.3(1)$ & - & & - \\
\hline & PPR* & $1.7(1)$ & - & $2.7(6)$ & - & & - \\
\hline \multirow{3}{*}{ Goat } & $\mathrm{FMD}^{*}$ & - & - & $28.4(63)$ & - & - & - \\
\hline & Contagious ecthyma & - & - & $4.1(09)$ & - & - & - \\
\hline & Black Quarter* & - & - & $2.3(05)$ & - & - & - \\
\hline \multirow{4}{*}{ Sheep } & $\mathrm{PPR}^{*}$ & $1.4(1)$ & - & $0.7(1)$ & - & $0.8(2)$ & - \\
\hline & FMD $^{*}$ & $2.1(2)$ & - & $1.3(3)$ & - & $0.5(1)$ & - \\
\hline & New castle disease* & $\begin{array}{l}32.3 \\
(614)\end{array}$ & - & $\begin{array}{c}75.0 \\
(2201)\end{array}$ & - & $\begin{array}{c}14.75 \\
(131.5)\end{array}$ & - \\
\hline & Pox* & $6.0(114)$ & - & $5.4(157)$ & - & $\begin{array}{c}1.37 \\
(12,25)\end{array}$ & - \\
\hline \multirow[t]{5}{*}{ Chicken } & NSRD & $1.1(21)$ & - & $8.8(257)$ & - & - & - \\
\hline & Parasitic infection & - & - & $0.9(25)$ & - & - & - \\
\hline & $\begin{array}{l}\text { Chicken Infectious } \\
\text { anaemia }\end{array}$ & - & - & $4.2(123)$ & - & - & - \\
\hline & Coccidiosis & $5.0(10)$ & - & - & - & - & - \\
\hline & Plague* & $1.9(46)$ & - & $21.0(57)$ & - & $5.39(10.25)$ & - \\
\hline Duck & Cholera & - & - & $4.1(11)$ & - & $15.13(28.75)$ & - \\
\hline
\end{tabular}

Source: Benchmark survey report, 2010 \& 2011 and field survey, 2012 \& 2013.

Note: Figures with in the parentheses indicate actual number. ${ }^{*}$ Vaccines supplied.

\section{Economic profile}

\section{Household income}

Table 7 reveals the household income of selected farm families from various sources. The table indicates a clear increase in the household income of farm families after the programme. Income from almost all sources was increased. Income from livestock rearing increases at a higher rate than other sources.
After the intervention, a considerable proportion of total income was coming from buck rearing in Naikhongchari $(7.13 \%)$. The impact of intervention on income in all the areas was statistically significant which was verified by the value of t-statistic. Ravallion test results showed the income was increased by the absolute amount of Tk. 32624.7, Tk. 30296.2 and Tk. 25611.4 due to intervention which were indicated as $38 \%, 27 \%$ and $25 \%$ increase in income of Belkuchi, Naikhongchari and Gangachara sampled farmers, respectively. 
Table 6 . Gender participation in livestock and poultry rearing

\begin{tabular}{|c|c|c|c|c|c|c|c|c|c|}
\hline \multirow{3}{*}{ Particulars } & \multicolumn{3}{|c|}{ Belkuchi } & \multicolumn{3}{|c|}{ Naikhongchari } & \multicolumn{3}{|c|}{ Gangachara } \\
\hline & \multicolumn{2}{|c|}{ Hour/day/person } & \multirow{2}{*}{$\begin{array}{c}\% \\
\text { impact }\end{array}$} & \multicolumn{2}{|c|}{ Hour $/$ day/person } & \multirow{2}{*}{$\begin{array}{c}\% \\
\text { impact }\end{array}$} & \multicolumn{2}{|c|}{ Hour/day/person, } & \multirow{2}{*}{$\begin{array}{c}\% \\
\text { impact }\end{array}$} \\
\hline & Before & After & & Before & After & & Before & After & \\
\hline \multicolumn{10}{|l|}{ A. Cattle } \\
\hline Male & 3.56 & 3.93 & 10.39 & 2.53 & 3.03 & 19.76 & 3.28 & 3.87 & 17.99 \\
\hline Female & 1.49 & 1.63 & 9.40 & 1.47 & 2.04 & 38.78 & 1.31 & 1.53 & 16.79 \\
\hline Child & 0.38 & 0.56 & 47.37 & 1.21 & 1.29 & 6.61 & 1.45 & 1.93 & 33.10 \\
\hline \multicolumn{10}{|c|}{ B. Goat and sheep } \\
\hline Male & 0.92 & 1.04 & 13.04 & 0.96 & 0.98 & 2.08 & 0.92 & 1.01 & 9.78 \\
\hline Female & 1.20 & 1.41 & 17.50 & 1.33 & 1.91 & 43.61 & 1.21 & 1.29 & 6.61 \\
\hline Child & 0.09 & 0.14 & 55.56 & - & - & - & 0.99 & 1.12 & 13.13 \\
\hline \multicolumn{10}{|l|}{ C. Chicken } \\
\hline Male & - & - & - & - & - & $=$ & - & - & - \\
\hline Female & 0.57 & 0.72 & 26.32 & 0.93 & 1.24 & 33.33 & 0.60 & 0.97 & 61.67 \\
\hline Child & 0.27 & 0.32 & 18.52 & 0.29 & 0.33 & 13.79 & 0.34 & 0.53 & 55.88 \\
\hline \multicolumn{10}{|l|}{ D. Duxk } \\
\hline Male & - & - & - & - & - & - & - & - & - \\
\hline Female & 0.55 & 0.58 & 5.45 & 0.54 & 0.80 & 48.15 & 0.54 & 0.74 & 37.04 \\
\hline Child & 0.31 & 0.44 & 41.94 & 0.29 & 0.40 & 37.93 & 0.30 & 0.48 & 60.00 \\
\hline \multicolumn{10}{|l|}{ E. Pigeon } \\
\hline Male & - & - & - & - & - & - & - & - & - \\
\hline Female & 0.25 & 0.36 & 44.00 & 0.85 & 0.90 & 5.88 & 0.61 & 0.77 & 26.23 \\
\hline Child & 0.37 & 0.53 & 43.24 & 0.29 & 0.32 & 10.34 & 0.20 & 0.39 & 95.00 \\
\hline
\end{tabular}

\section{Household expenditure}

After the program, the farmers were in better position to earn more income and lead a better life than before. As a consequence, their household expenditure was increased. Respondents were spending most of their increased income on dwelling houses. Educational expenses were also more than before. However, expenses on health management were decreased as the farm families, were consuming more livestock products (meat, milk and egg). About 69\%, $49.39 \%$ and $68.13 \%$ of total share was spent for food items in Belkuchi, Naikhongchari and Gangachara, respectively. Ravallion test results showed the expenditure was increased by the absolute amount of $\mathrm{Tk}$. 7725.6, Tk. 12728.7 and Tk. 5160.7 due to intervention which were marked as $11 \%$, $13 \%$ and $9 \%$ increase in expenditure of Belkuchi, Naikhongchari and Gangachara sampled farmers, respectively (Table 8 ). 
Table 7. Annual household income of farm families (Tk.)

\begin{tabular}{|c|c|c|c|c|c|c|}
\hline \multirow[t]{2}{*}{ Sources of income } & \multicolumn{2}{|c|}{ Belkuchi } & \multicolumn{2}{|c|}{ Naikhongchari } & \multicolumn{2}{|c|}{ Gangachara } \\
\hline & Before 1 & After & Before & After & Before & After \\
\hline 1. Crop production & $\begin{array}{l}9016.8 \\
(10.50)\end{array}$ & $\begin{array}{l}10820.2 \\
(9.89)\end{array}$ & $\begin{array}{l}27635.0 \\
(25.00)\end{array}$ & $\begin{array}{l}33162 \\
(23.63)\end{array}$ & $\begin{array}{r}17705.2 \\
(17.03)\end{array}$ & $\begin{array}{r}20203.5 \\
(15.96)\end{array}$ \\
\hline $\begin{array}{l}\text { 2. Livestock rearing } \\
\text { (i) Backyard rearing }\end{array}$ & $\begin{array}{l}2068.3 \\
(2.40)\end{array}$ & $\begin{array}{l}8970.0 \\
(8.21)\end{array}$ & $\begin{array}{l}8553.8 \\
(7.77)\end{array}$ & $\begin{array}{l}8553.8 \\
(6.10)\end{array}$ & $\begin{array}{l}3515.5 \\
(3.38)\end{array}$ & $\begin{array}{l}7178 \\
(5.67)\end{array}$ \\
\hline (ii) Buck rearing & $\begin{array}{c}0 \\
(0.00)\end{array}$ & $\begin{array}{c}0 \\
(0.00)\end{array}$ & $\begin{array}{c}0 \\
(0.00)\end{array}$ & $\begin{array}{l}10000 \\
(7.13)\end{array}$ & $\begin{array}{c}0 \\
(0.00)\end{array}$ & $\begin{array}{c}0 \\
(0.00)\end{array}$ \\
\hline $\begin{array}{l}\text { 3. Homestead based enterprises } \\
\text { (gardening, nonfarm sources, } \\
\text { etc.) }\end{array}$ & $\begin{array}{l}625.8 \\
(0.70)\end{array}$ & $\begin{array}{l}750.9 \\
(0.69)\end{array}$ & $\begin{array}{c}4669.26 \\
(4.24)\end{array}$ & $\begin{array}{l}5603.1 \\
(3.99)\end{array}$ & $\begin{array}{l}764.7 \\
(0.74)\end{array}$ & $\begin{array}{l}954.5 \\
(0.75)\end{array}$ \\
\hline 4. Business & $\begin{array}{r}23766.6 \\
(27.70)\end{array}$ & $\begin{array}{r}28519.9 \\
(26.09)\end{array}$ & $\begin{array}{l}25965.6 \\
(23.59)\end{array}$ & $\begin{array}{l}31158.7 \\
(22.20)\end{array}$ & $\begin{array}{l}23234.8 \\
(22.35)\end{array}$ & $\begin{array}{l}29845 \\
(23.58)\end{array}$ \\
\hline 5. Service & $\begin{array}{l}18522.4 \\
(21.60)\end{array}$ & $\begin{array}{r}22226.9 \\
(20.33)\end{array}$ & $\begin{array}{l}30522.9 \\
(27.74)\end{array}$ & $\begin{array}{l}36627.5 \\
(26.10)\end{array}$ & $\begin{array}{r}25976.7 \\
(24.98)\end{array}$ & $\begin{array}{l}31500.8 \\
(24.89)\end{array}$ \\
\hline 6. Agril. and nortagril, labour & $\begin{array}{l}31683.3 \\
(37.00)\end{array}$ & $\begin{array}{l}38019.9 \\
(34.78)\end{array}$ & $\begin{array}{l}12688.0 \\
(11.53)\end{array}$ & $\begin{array}{l}15225.6 \\
(10.85)\end{array}$ & $\begin{array}{l}32772.9 \\
(31.52)\end{array}$ & $\begin{array}{l}39899.4 \\
(31.52)\end{array}$ \\
\hline Total annual income & $\begin{array}{l}85683.2 \\
(100.00)\end{array}$ & $\begin{array}{l}118307.9 \\
(100.00)\end{array}$ & $\begin{array}{l}110034.6 \\
(100.00)\end{array}$ & $\begin{array}{l}140330.7 \\
(100.00)\end{array}$ & $\begin{array}{l}103969.8 \\
(100.00)\end{array}$ & $\begin{array}{l}129581.2 \\
(100.00)\end{array}$ \\
\hline $\begin{array}{l}\text { Impact of intervention on income } \\
\text { (Tk.) (Ravalion test result) }\end{array}$ & 326 & $24.7 *$ & 3029 & $6.2 * *$ & 256 & $1.4^{*}$ \\
\hline t-value & & 56 & & 1 & & 89 \\
\hline $\begin{array}{l}\text { Impact of intervention on income } \\
\text { (percentage change) }\end{array}$ & & 38 & & & & 5 \\
\hline
\end{tabular}

Source: Benchmark survey report, $2010 \& 2011$ and field survey, 2012 \& 2013. Note: Figures with in the parentheses indicate percentages of total. ${ }^{* *}$ Significant at 5 percent level. * Significant at 10 percent level.

\section{Expenditure elasticity}

Estimated expenditure elasticities for a group of commodities in three locations after intervention are shown in Table 8. Expenditure elasticity was estimated at 0.34 and 0.36 in Belkuchi and Gangachara, respectively which means that expenditure increased by $0.34 \%$ and $0.36 \%$, on an average, due to $1 \%$ increase in income, other things remaining the same in two regions. On the other hand, the value of estimated expenditure elasticity in Naikhongchari
(0.53) was higher than other areas which means that the expenditure in Naikhongchari increased by $0.53 \%$ in response to a $1 \%$ increase in income.

\section{Asset possession}

Farmers' overall income was enhanced and as a result they spent more for making dwelling house, furniture, luxury items like mobile phone, TV, fan, etc. Their overall livelihood status was improved. 
Table 8. Annual household expenditure of farm families

\begin{tabular}{|c|c|c|c|c|c|c|}
\hline \multirow{2}{*}{ Particulars } & \multicolumn{2}{|c|}{ Belkuchi } & \multicolumn{2}{|c|}{ Naikhongchari } & \multicolumn{2}{|c|}{ Gangachara } \\
\hline & Before & After & Before & After & Before & After \\
\hline \multirow[t]{2}{*}{ Food } & \multirow{2}{*}{$\begin{array}{l}41175.7 \\
(69.57)\end{array}$} & 46157.6 & 45403.6 & 49358.0 & 44957.9 & 47450.5 \\
\hline & & $(68.97)$ & $(52.06)$ & $(49.39)$ & $(71.69)$ & $(68.13)$ \\
\hline \multirow[t]{2}{*}{ Clothing } & \multirow{2}{*}{$\begin{array}{l}5391.1 \\
(9.11)\end{array}$} & 6380.1 & 9065.6 & 10714.3 & 4859.4 & 5150.4 \\
\hline & & $(9.53)$ & $(10.39)$ & $(10.72)$ & $(7.67)$ & $(7.40)$ \\
\hline \multirow[t]{2}{*}{ Health management } & \multirow{2}{*}{$\begin{array}{l}3743.0 \\
(6.32)\end{array}$} & 3649.0 & 8919.7 & 8472.6 & 3528.5 & 3242.3 \\
\hline & & $(5.45)$ & $(10.23)$ & $(8.48)$ & $(5.64)$ & $(4.66)$ \\
\hline \multirow[t]{2}{*}{ Education } & \multirow{2}{*}{$\begin{array}{l}3310.4 \\
(5.59)\end{array}$} & 3975.8 & 5837.2 & 6741.9 & 4513.8 & 5478.2 \\
\hline & & $(5.94)$ & $(6.69)$ & $(6.75)$ & $(7.11)$ & $(7.87)$ \\
\hline \multirow[t]{2}{*}{ Cosmetics } & \multirow{2}{*}{$\begin{array}{r}2965.8 \\
(5.01)\end{array}$} & 3507.7 & 1567.9 & 2322.1 & 2533.1 & 3320 \\
\hline & & $(5.24)$ & $(1.79)$ & $(2.32)$ & $(4.05)$ & $(4.77)$ \\
\hline $\begin{array}{l}\text { Others (personal expenses, house } \\
\text { construction) }\end{array}$ & $\begin{array}{l}2741.8 \\
(4.63)\end{array}$ & $\begin{array}{l}3253.0 \\
(4.86)\end{array}$ & $\begin{array}{l}16418.6 \\
(18.83)\end{array}$ & $\begin{array}{r}22332.3 \\
(22.35)\end{array}$ & $\begin{array}{l}2398.6 \\
(3.83)\end{array}$ & $\begin{array}{l}3000.6 \\
(4.30)\end{array}$ \\
\hline Totalannual expenditure & $\begin{array}{l}\mathbf{5 9 1 9 7 . 6} \\
(10000)\end{array}$ & $\begin{array}{l}66923.2 \\
(100.00)\end{array}$ & $\begin{array}{l}87212.5 \\
(100.00)\end{array}$ & $\begin{array}{l}99941.2 \\
(100.00)\end{array}$ & $\begin{array}{l}62481.3 \\
(100.00)\end{array}$ & $\begin{array}{l}67642.0 \\
(100.00)\end{array}$ \\
\hline $\begin{array}{l}\text { Impact of intervention on expenditure } \\
\text { (Tk.) (Ravallion test result) }\end{array}$ & \multicolumn{2}{|c|}{$7725.6^{* *}$} & \multicolumn{2}{|c|}{$12728.7^{* * *}$} & \multicolumn{2}{|c|}{$5160.7 *$} \\
\hline t-value & \multicolumn{2}{|c|}{4.51} & \multicolumn{2}{|c|}{1.98} & \multicolumn{2}{|c|}{2.10} \\
\hline $\begin{array}{l}\text { Impact of intervention on expenditure } \\
\text { (percentage change) }\end{array}$ & \multicolumn{2}{|c|}{11} & \multicolumn{2}{|c|}{13} & \multicolumn{2}{|c|}{9} \\
\hline Expenditure elasticity $(\%)$ & \multicolumn{2}{|c|}{0.34} & \multicolumn{2}{|c|}{0.53} & \multicolumn{2}{|c|}{0.36} \\
\hline
\end{tabular}

Source: Benchmatk survey report, 2010 \& 2011 and field survey, 2012 \& 2013. Note: Figures within the parentheses indicate percentages of total. ***Significant at 1 percent level and ${ }^{* *}$ Significant at 5 percent level.

Household asset inventory of the farm families indicate that each farm family owned more than one dwelling house for their shelter with an average of 1.97 in Belkuchi, 2.04 in Naikhongchari and 2.07 in Gangachara (Table 9). Number of houses per family amplified with increased farm size. A few people also owned television, fridge and some agricultural implements (crusher, STW and power pump).

\section{Household consumption}

Findings indicate that resource poor farm families purchased rice in addition to their own production (Table 10). All of the farm families bought ata and pulse. Production of culture fish was small as the natural water body was few. Therefore, farmers had to purchase more than $50 \%$ of consumed fish.

A considerable amount of fish was procured from open water fishing during monsoon season. Similarly, about two-third of the consumed meat was from exogenous sources i.e. market, neighbours, relatives, etc. A good amount of milk and eggs was supplied from household livestock and poultry resources. Major portion of vegetables were procured from the local market in addition to household production. 
Table 9. Asset possession of farm families (Number per farm)

\begin{tabular}{|c|c|c|c|c|c|c|c|c|c|}
\hline \multirow[t]{2}{*}{ Assets } & \multicolumn{3}{|c|}{ Belkuchi } & \multicolumn{3}{|c|}{ Naikhongchari } & \multicolumn{3}{|c|}{ Gangachara } \\
\hline & Before & After & $\begin{array}{c}\% \\
\text { change }\end{array}$ & Before & After & $\begin{array}{c}\% \\
\text { change }\end{array}$ & Before & After & $\begin{array}{c}\% \\
\text { change }\end{array}$ \\
\hline \multicolumn{10}{|l|}{ A. House } \\
\hline $\begin{array}{l}\text { i. Dwelling } \\
\text { house }\end{array}$ & 1.43 & 1.97 & +38 & 1.52 & 2.04 & +34 & 1.96 & 2.05 & +5 \\
\hline ii. Animal shed & 0.23 & 0.33 & +43 & 0.41 & 0.62 & +51 & 0.94 & 1.10 & +17 \\
\hline iii. Other houses & s 0.48 & 0.52 & +8 & 0.17 & 0.19 & +12 & 0.86 & 0.88 & 2 \\
\hline \multicolumn{10}{|l|}{ B. Furniture } \\
\hline i. $\operatorname{Cot}$ & 1.86 & 1.92 & +3 & 1.67 & 1.93 & +16 & 2.08 & 2.11 & +1 \\
\hline ii. Chair & 3.25 & 3.62 & +11 & 2.83 & 3.12 & +10 & 2.59 & 2.85 & +10 \\
\hline iii. Table & 1.01 & 1.26 & +25 & 0.93 & 1.08 & +16 & 1.21 & 1.32 & +9 \\
\hline iv. $A \ln a$ & 1.06 & 1.28 & +21 & 0.81 & 0.82 & +1 & 1.08 & 1.10 & +2 \\
\hline v. Sofa & 0.07 & 0.13 & +86 & 0.17 & 0.18 & +6 & 0.11 & 0.12 & +9 \\
\hline vi. Wardrobe & 0.09 & 0.19 & +111 & 0.19 & 0.21 & +11 & 0.06 & 0.11 & +83 \\
\hline \multicolumn{10}{|c|}{ C. Household luxury } \\
\hline i. Mobile phone & 0.71 & 1.88 & +165 & 0.56 & 1.32 & +136 & 0.52 & 0.86 & +65 \\
\hline ii. Radio : & 0.12 & 0.10 & -17 & 0.04 & 0.03 & -25 & 0.01 & 0.00 & -100 \\
\hline iii. Electric fạn & 0.98 & 1.27 & +30 & 0.59 & 0.69 & +17 & 0.66 & 0.73 & +11 \\
\hline iv. Television & 0.21 & 0.28 & +33 & 0.13 & 0.17 & +31 & 0.35 & 0.41 & +17 \\
\hline iv. Fridge : & 0.03 & 0.06 & +100 & 0.05 & 0.08 & +60 & 0.02 & 0.03 & +50 \\
\hline \multicolumn{10}{|c|}{ D. Agricultural equipment } \\
\hline i. Power tiller & - & 0.02 & - & 0.08 & 0.10 & +25 & 0.01 & 0.08 & +700 \\
\hline ii. Crusher & 0.06 & 0.08 & +33 & 0.07 & 0.09 & +29 & - & 0.02 & - \\
\hline iii. STW & 0.07 & 0.10 & +43 & 0.05 & 0.06 & +20 & 0.06 & 0.08 & +33 \\
\hline iv. Power pump & 0.01 & 0.02 & +100 & 0.02 & 0.02 & 0 & 0.12 & 0.14 & +17 \\
\hline
\end{tabular}

Source: Benchmark survey report, $2010 \& 2011$ and field survey, $2012 \& 2013$.

After the programme, farmers' overall consumption of all food items was increased (from $1147.5 \mathrm{gm}$ to $1177.3 \mathrm{gm}$ per day per capita in Belkuchi, from $1068.4 \mathrm{gm}$ to $1089.6 \mathrm{gm}$ per day per capita in Naikhongchari and $1147.1 \mathrm{gm}$ to $1172.3 \mathrm{gm}$ per day per capita in Gangachara). The changes in per capita daily food intake were statistically significant at 10 percent probability level as confirmed by the values of $\mathrm{t}$ - statistic in the areas.

\section{Conclusion}

The benchmark findings indicated that a considerable number of farmers had no cropland and were mostly dependent on daily labour selling. Number of livestock and poultry species was lower due to shortage of feed and disease outbreak. Productivity of these animals was also poor in the villages. The FMD and ND were the major diseases heavily affecting morbidity and mortality as well as productivity of animals. After three 
Table 10. Consumption of different food items (gm/day/capita)

\begin{tabular}{|c|c|c|c|c|c|c|}
\hline \multirow[t]{2}{*}{ Food items } & \multicolumn{2}{|c|}{ Belkuchi } & \multicolumn{2}{|c|}{ Naikhongchari } & \multicolumn{2}{|c|}{ Gangachara } \\
\hline & Before & After & Before & After & Before & After \\
\hline Rice own & 429.3 & 431.2 & 481.8 & 483.1 & 436.2 & 440.1 \\
\hline Rice purchased & 349.1 & 350.5 & 200.0 & 201.5 & 327.8 & 329.4 \\
\hline Ata & 44.0 & 45.6 & 40.2 & 44.2 & 45.0 & 46.0 \\
\hline PuIse & 26.3 & 28.3 & 23.8 & 25.3 & 25.9 & 27.4 \\
\hline Fish & 49.4 & 53.2 & 37.7 & 39.8 & 51.4 & 55.6 \\
\hline Meat & 18.7 & 21.7 & 21.8 & 25.6 & 22.1 & 26.1 \\
\hline Milk & 46.7 & 50.4 & 55.0 & 57.3 & 51.1 & 54.7 \\
\hline Egg & 3.1 & 4.2 & 4.2 & 4.9 & 0.1 & 0.3 \\
\hline Vegetable & 180.9 & 194.2 & 203.9 & 207.9 & 187.4 & 192.7 \\
\hline Total & 1147.5 & 1177.3 & 1068.4 & 1089.6 & 11.47.1 & 1172.3 \\
\hline $\begin{array}{l}\text { Change in per capita } \\
\text { daily food intake }\end{array}$ & \multicolumn{2}{|c|}{$29.8^{*}$} & \multicolumn{2}{|c|}{$21.2^{*}$} & \multicolumn{2}{|c|}{$25.2^{*}$} \\
\hline t-value & \multicolumn{2}{|c|}{2.67} & \multicolumn{2}{|c|}{2.02} & \multicolumn{2}{|c|}{1.96} \\
\hline
\end{tabular}

Source: Benchmark survey report, $2010 \& 2011$ and field survey, $2012 \& 2013$.

Note: * Significant at 10 percent level.

years, impact study results indicated positive response to technological and health management interventions in regard to reduced mortality and increased productivity. Marketing facilities were improved. New avenues of employment were created. Farmers' income was increased. As a result, their housing and household asset possession were enriched, per capita daily food consumption was improved and thereby their overall socioeconomic conditions was enhanced. Farmers' awareness for technology Table 10. Consumption of different food items (gm/day/capita).

Although there is slight social conflict among the recipients and neighbouring villages, all farmers requested the team members of the impact study to continue the programme for two years more along with the supply of some good breed of buck to ensure the proper natural services of goat in the villages as the kids were healthy and energetic. However, impact study based on three years data for three locations may not adequately represent the true picture of the community. It is also suggested to add more locations based on geographical variability to test the model prior to large-scale dissemination. Finally, it can be recommended that the programme may be replicated to other locations with new interventions like distribution of buck and sheep and HYV fodder in order to augment farmers' income and livelihood improvement.

\section{References}

BBS 2010. Statistical Yearbook of Bangladesh, Bangladesh Bureau of Statistics, Statistics Division, Ministry of Planning, Government of the People's Republic of Bangladesh, Dhaka. 
Begum, J., Raha, S. K., Uddin, M. T. and Fatema, J. 2010. A study on milk marketing in selected areas of Bangladesh. Proceedings of the Annual Research Review Workshop, Bangladesh Livestock Research Institute, Savar, Dhaka, pp 330-348.

Kamaruddin, K. M. 2002. Goat production in Bangladesh: present status and future prospects. Khamar: A monthly magazine on poultry, livestock and fisheries, Dhaka, July-August 2002, 11-15.

Hossain, S.M.A. and Nessa, J. 2005. Studies on Livelihood Improvement through Integrated Farming. Final Report submitted to the Research Initiatives Bangladesh, Bangladesh Agricultural University, Mymensingh, Bangladesh.

Rabbani, M.S., Alam, M.M., Ali, M.Y., Rahman, S.M.R. and Saha, B.K. 2004. Participation of rural people in dairy enterprise in a selected area of Bangladesh. Pakistan Journal of Nutrurion, 3(1): 29-34.

Rahman, H. 2010. Need assessment on veterinary services: availability and cost of animal health services in MFTS project areas. Final Research Project Report Submitted to Palli Karma-Sahayak Foudation, Sher-e-Bangla Nagar, Dhaka-1207.
Rahman, M.S., Monaym, M.A. and Rahman, M.H. 2000. Dairy cow rearing efficiency in income and employment: A study of two areas of Bangladesh, Bangladesh Journal of Animal Science. 29(1\& 2): 11-20.

Ravallion, M. 2008. Evaluating anti-poverty programs. In T. Paul Schultz \& John A. Struass (ed.), Handbook of development economics, Elsevier, edition 1, vol 4, no. 5, chapter 59, pp 3787-3846.

Talukder, R. K., and Uddin, M. T. 2000. Economics of Milk Production in Bangladesh. A Contract Research Report Submitted to Bangladesh Agricultural Research Council, Farmgate, Dhaka-1215.

Uddin, M. T., Islam, M.M, and Nasrin, M. 2011. Impact of recent changes in livestock production pattern on farm families' livelihood and health in selected areas of Bangladesh. Bangladesh Journal of Livestock Research, 18 (1\&2): 52-69. 